\title{
THE COMPANY SYSTEM IN CAPE COAST CASTLE
}

IT is not easy to describe the customs of even the Fantispeaking tribes of the Gold Coast Colony with any degree of accuracy, as they vary in detail with each tribe, and are appreciably affected by the advance of civilisation.

In describing the Company system, therefore, I have selected Cape Coast Castle as my model, as this is the largest town in the Colony, 'and the Company customs are here still jealously guarded, although to some extent modified by the increasing size of the town; and, as it was until 1877 the headquarters of the Colony, the inhabitants have been most in touch with the outer world.

I have further had the advantage of being stationed there for a period extending over two years, and I have interested myself in investigating Fanti customs generally, cutling my. information from chiefs and their councillors throughout the District, and from captains and important men in Cape Coast itself.

The original founders of the town are said to be the Bentils and the Inkums from Sekyere, north-east of Iumase, who settled on Effutu land, and absorbed the Effutus.

The Bentils are now known as No. I Company, and the Inküms as No. 4. These two companies increased in numbers, and were finally each split up into two: the Anafo, or No. 2 Company, sprang from Bentil, and took its name from arafo, which means "low town," from the position of its new quarters; while the Intsin Company sprang out of the Inküm, and are designated No. 3 . The Intsins first settled on land which was near the site of the present castle, and when the castle was built, they were ordered to move further away (intsin means "to stretch further "). 
When the Swedes first settled at Cabo Corso (the original name of Cape Coast), in 1652, they introduced men and women from the Leeward coast, chiefly from Benin, and even bought people in the town, to train them as bricklayers, coopers, blacksmiths, and artisans; with these strangers they built the castle, and assigned to these slaves the land near the castle. In course of time these strangers formed themselves into a Company, No. 5, under the name of Brofu-Mba (white men's children), or Brofu-Nkua (white men's slaves). This was the beginning of the real expansion of Cape Coast. The castle was originally called Carolusburg, but reverted to the old name, Cabo Corso, under the Danes and the Dutch between 1658 and 1663 , and finally took the name of Cape Coast Castle under the English in 1664.

This influx of Europeans, in an unhealthy climate, and far from their homes, naturally led to the birth of a large number of mulattoes, who intermarried, and these became in time sufficiently numerous to form No. 6 Company, or Akrampa (which means mulatto).

Finally, the Danes brought artisans from the Accra district, and settled them along the coast, a little east of the main town; these became No. 7 Company, and were called the Amanfur Company (from Aman, a race, and Fufuro, new).

Since 1659 other natives have settled in Cape Coast, and at present the nomadic traders, who pass on the Coast under the general name of Hausa, are probably more numerous than the Fanti population, but no more Companies have been formed.

The members of Nos. 5, 6, and 7, although of foreign extraction, have assimilated the Fanti language and customs, whereas all later comers have kept their own.

Natives are very reticent on the subject of their customs, so it is very difficult to learn the truth; their language has no orthography, and it remained unwritten until after the middle of the last century. Hence they have no literature, and I have attempted to minimise any errors I may have fallen into by consulting as many sources as appeared necessary to make things clear. 
In the Gold Cosst Colony, each race, or Oman, consists of a number of small communities, living in their respective towns or villages, under their respective chiefs (Ohin, pl. Ahin) or headmen (Ponyin, pl. Mpenyinfo).

The people collectively recognise one of their chiefs, generally the wealthiest, or the most powerful, as the head of the Oman.

The term " king" was too ambitious a title to give to this personage, so the Gold Coast Government has adopted the native word Omanhin (pl. Amanhin, from Oman, people, and Ohin, chief), to describe him.

The Omanhin is the paramount chief of the district over which he rules, and he is the principal magistrate over his people; each chief has his own jurisdiction over his own particular community, but the Omanhin has an inherent right of appeal from the decisions of his chiefs, and he has special privileges, inasmuch as his fines are very much heavier than those of his chiefs, and he takes precedence over them at general assemblies.

In the fighting line, he was (in the days when native chiefs could still make war on their own account) the fighting general of the rear guard, and his duty was to wait there and send forward reserves, ammunition, and men as required. $\mathrm{He}$ only took part in the actual fighting when pressing home the final charge in case of victory.

The head of the fighting line was the Tufuhin (pl. Etufuhin) or Captain-general. This officer directed the fighting and gave all the orders.

The Omanhin assembled the people, consulted them, and declared war; the Tufuhin then took charge of the actual fighting, until ordered by the Omanhin to retire.

Each Oman presumably originated from a single village community. So we still see villages, when they get beyond a certain size, split up, owing either to a disruption or to a scarcity of food; the seceding part of the inhabitants going further into the bush, there to open up new farms, and start

\footnotetext{
1 [This whs atoo done by the Yeo chiefs-(eee Duff Mecdonald, Africana)-who remained in the rear "to expply powder and deal with deserters" The line was led bs the "Sactifices" who took the omens before the buttle -ED.]
} 
a new village, under a new headman, but recognising in nearly every case the old village as the parent.

The headman of each village is Captain (Osafohin, pl. Asafohinfo) of the fighting force which that village can muster, and if he has seceded from another village, he considers himself a sub-captain of the headman of the old village. When a captain, directly under an Omanhin, has several such sub-captains, he assumes the political title of "Ohin," or chief.

Thus the ordinary oman in the Colony consists of a number of small scattered villages, or companies, under their respective captains, and these Companies form the fighting force of the Oman.

Amongst the Fanti speaking races we find the usual formation of the army is a Van-guard (Twafo), under the Twafohin; the Centre (Dentsifo), under the Dentsifohin; and the Rearguard (Nchidom), which included the Gyasifo, or immediate body-guard of the Omanhin, i.e., the band attached to the stool.

At Cape Coast Castle, where there are seven Companies, the disposition of the army is as follows :-

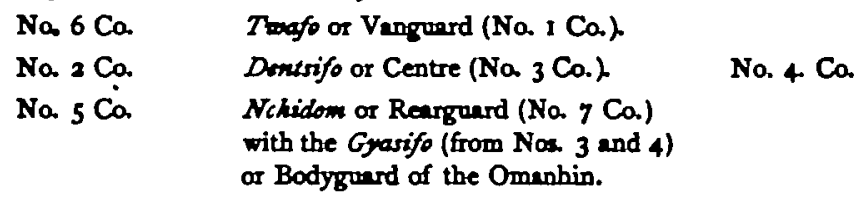

Whereas the disposition of the usual native army in the Twispeaking races, and in Ashanti, is a division of all the towns of the oman into a right wing, left wing, centre, and rearguard. For example, the Denkeras, who were once the predominant race in Ashanti, but were subjugated by the Ashantis about the year 1719 , and migrated from Kumase about the year 1824, still retain their old formation as follows :-

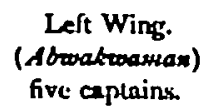

$$
\begin{aligned}
& \text { Centre. } \\
& \text { (Adamisinfo) } \\
& \text { six coptains. }
\end{aligned}
$$$$
\text { Rearguerd. }
$$$$
\text { (Gyasifo) }
$$$$
\text { fourteen captuins. }
$$

With the Omanhin and his family (Adickt) in the rear. 
When several such Aman combined to meet a common foe, as when Ashanti invaded the Coast, the several Amanhin met and appointed one of themselves, Osahin, or Generalissimo. He took charge of the entire army, and gave orders to the several Etufuhin, who in turn commanded the respective Aman.

Each Company, when it was ordered to attack, had to go to the front, and the battle was waged by a succession of such attacks.

I have now given only the principal officers of the Oman, namely, the Omanhin, or political head, the Tufuhin, or military head, the Twafohin, or commander of the vanguard, and the Dentsifohin (in some parts called the Dontsinhin), or commander of the centre; but, in addition to these, each Company has officers of its own, for the regulation of its own affairs.

Chief amongst these is the $S u p i$, or principal captain. The word supi means a pot brimful of water, and as water is essential to life, so is the Supi essential to the life of each Company; he takes orders from the Tufuhin and transmits them to the other captains of his Company, and nothing connected with the Company can be done without the knowledge and consent of the Supi. He keeps all the powder, flags and other Company paraphernalia, and superintends the general deportment of the Company. His emblems of office are a captain's whip, and a long dagger. In times of peace he has to be consulted on every event of interest to the Company.

Next to him are the Asafohinfo (sing. Osafohin), or junior captains, to whom the Supi details his orders. Their emblems are the captain's whip, and a short dagger. It is their duty to keep order with these whips, and if necessary even with the dagger. The whips are made from twisted bull's or hippopotamus's hide. Captains, in carrying out their orders, use these whips very freely, and it is remarkable to see how a crowd submits to their lashes, even on the verge of a riot, when I have seen three or four men keep back a surging mass of humanity with these whips alone when making for their opponent Company, not a hundred yards 
off, who were in turn being beaten back in a similar manner by their captains.

Next in importance are the Asafompenyin, or Company elders. These, as the name implies, are old men (Mpenyin), who are elected by the Company at a general meeting to consult on matters of importance, and to settle disputes amongst members of the Company. Any man of known wisdom may be selected, and normally he remains an elder for the rest of his life. Others are elected as the numbers are found to diminish from natural causes, and sometimes experts are temporarily elected for special cases. The Asafompenyin have no emblem, but to be elected is considered a very great honour; the office, not being hereditary, is not limited in numbers.

The Bomba, again, are men who hold office from father to son, and each Company has normally two Bomba, whose duty it is, whenever the Company turns out for festive occasions, as, for example, the funeral of its seniors, to keep order with a whip like a rope, and they may resort to a form of cudgel.

Then there is the Asikanmbahin, or the head of the supporters of the Company's flags (from Osika, pl. Asikan, a knife; $B a$, pl. $M b a$, child; and $O h i n$, chief). He keeps the flags and gives them out as he chooses when the Company is on the march. He also keeps the Asikanmba in order with a Captain's whip, and he carries twelve knives, whilst his supporters carry six each round their waists, three on each side, for the purpose of defence.

The Franka-Kitikin, or Impokiti Franki, are the actual flag-bearers, to whom the Asikanmbahin assigns the flags, when on the march; each Company has two, but they have no emblems when not carrying the flags.

There are usually twelve Asikanmba, or supporters, in times of peace, but this number is increased in war to some multiple of twelve, generally thirty-six. This increase is probably due to the fact that, in peace, if the proper man is sick, or old, his son or grandson may act, but in war the old men themselves must do their work, and those who have acted for them continue, in addition. Their duty is to go out 
THE COMPANY SYSTEM IN CAPE COAST CASTLE 267

first, and to entice the enemy to open fire and discover themselves, as the principal object of fighting is to capture the flag, or some other Company emblem.

The Kyerema, or drummer, beats the Company drum, by means of which all instructions are given, to assemble, march, advance, halt, retire, exactly as buglers sound the necessary orders amongst civilised races. There are generally two drummers to each Company, and each Company has its own call to assemble; but the other calls, such as the advance, halt, and retire, are common to all the companies. If only one Company is to carry out a manœuvre the call is preceded by first beating that Company's particular call.

The Abrafo are the executioners of the Company, and their emblem is a knife, like an ordinary kitchen knife, with which they attack their victims. Their duty in battle is to behead those of the enemy killed on the field, who are not removed by their comrades. Every head must be taken to the Tufuhin, who presents it to the Omanhin, and he has the skulls placed on the Bombaai, or war-drums, whilst the jaw-bones are placed on his war-horns. The Omanhin may present the skull to the Tufuhin, or, in cases of special valour, to the person who slew the opponent, and such hero might, in addition, be raised to the rank of Captain.

In peace the Abrafo also found work to do. When the Company makes any "fetich" custom, blood has to be spilt; this was formerly human blood, but is now generally that of sheep or goats. The Supi and the Asafompenyin decide who are to be executed, the Supi then gives the Abrafo the order, and these proceed, in cold blood, to carry it out. The procedure is to catch the victim unawares, either by lying in ambush, or by approaching him in his sleep, and to run the knife through both cheeks, to prevent his speaking; for if he can now only mutter a chief's oath, the Abrafo must release him or be treated as a murderer.-A chief's oath is a challenge to appear, with the swearer, before the chief whose oath is sworn, for explanations, and, once sworn, neither party may prevent the other from appearing.-The Abrafo, having thus silenced his man, proceeds to stun him, 
and then severs the head from the body, by hacking at the nape of the neck. When severed, the head is placed on the Company-post of the executing Abrafo, and after decomposition sets in, he removes it to his house, scrapes the skull with his knife, and stores the cleaned trophy inside the Company-post, placing the lower jaw-bone on the Company drums or horns. Victims for these festivities are nearly always strangers, but if strangers are fortunate enough to be scarce, then slaves are proscribed.

The bodies of these victims are in some parts buried, until partial decomposition sets in, when the Company's warweapons, spears and arrows, are stuck into the putrid earth; this produces fatal results from tetanus, when the weapons are effectively used within a certain period. This poisoning of weapons forms part of the war-dance of some of the Coast tribes, prior to going on the war-path. Stealth is always practised by the Abrafo, and, generally, treachery; for instance, if he knows the stranger is residing in the house of a member of the Company, he meets the host and tells him to see that his guest is at a certain lonely spot at a certain hour; the man knows what this means, is bound to secrecy, and has to carry out his part, while the Abrafo, waiting at the appointed spot, does the rest. The last time such an execution is admitted to have taken place, in Cape Coast Castle, was in 1874 during Sir Garnet (now Lord) Wolseley's expedition, when the Fanti proscribed all Ashantis on the Coast. Prince Ansa, the son of an Ashanti chief, was detained on parole when the Abrafo entered his house, and, stabbing all his household, took them down to the foreshore, where they severed their heads, and buried them on the spot, which was forthwith declared to be "fetich," and is now the site of the market sheds. Prince Ansa himself was only saved because he was a hostage of the troops.

The only Company officials left to be described are the " horn-blowers," who have no designation in common to all the companies, but take their name from the particular instrument appropriated by their Company. Thus at Cape Coast Castle a trumpet, made originally from an elephant's tusk, but now of brass, was the war-horn of the Bentil Company, 
and that Company's horn-blower is named Driohem Akessem (the one who blows the trumpet).

Finally, there are the ordinary members or fighting force of the Company. These, and all the Company officers, with

the sole exception of the Asafompenyin, are succeeded by their sons, as the martial spirit is said to descend from the father. Thus the Company system is quite distinct from the family, or tribal, system of West Africa, which latter traces descent through the female. A man and his wife must belong to different families, as marriages in the same family are prohibited, and the children, both male and female, belong to the mother's family-on the principle that it is a wise father who knows his own son. If both father and mother belong to the same Company, which is often the case, the children necessarily belong to the Company of mother as well as father; but where a man of one Company marries a woman of another Company, which is the general rule, the children, both male and female, belong to the father's Company, although they still remain members of the mother's family. ${ }^{1}$

These connections, both tribal and military, are very jealously guarded, and many a riot has been occasioned by one Company giving a public funeral to a person whom another Company considers to be one of its sons.

A Supi's eldest son succeeds him as Supi, whereas his eldest surviving brother, or if he has no brothers, the eldest child of his sister succeeds him as heir to his property. In the same way, the offices of Asafohin, Bomba, Asikanmba, Franki-Kitihin, Kyerema, and Abrafo, all descend from father to son; but a chief is succeeded as chief by one of his brothers or nephews, not necessarily the eldest, and this varies in different parts.

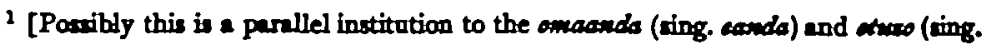
onum) of the Hereros. Every Herero belongs both to an acada and an onves, the former (which may be tranilated "clan") being that of his mother, the hatter (a rehtion of a purely ceremonial chanacter) that of bis father. There are eight principal amaonda, some of which are sub-divided into leser clens. The aturo are much more numerous. Viehe enomentes 16, but ates that his list is not complete. Eech arwar hes some probibition releting to food, and a story to account for it See a paper by the bate Rev. G. Viebe, in Transaction of the Berlin Oriental Seminary (Part III: Africarische Strodion) for Igon. - ED.]
} 
In Cape Coast Castle and Anamaboe we find a Company system entirely different from that prevalent on the rest of the coast. The Cape Coast Fanti are said to have migrated, centuries ago, from Sekyere, north-east of Kumase; they reached the Coast, and settled on Effutu land, and have practically absorbed the Effutus, who are now represented by one village of that name a few miles out of Cape Coast Castle.

The race that originally settled in Cape Coast consisted of two Companies, the Bentil Company, and the Inküm. Instead of forming different villages, they took up quarters in the same town, and, from various causes, other Companies were formed, which established their own quarters in the town, and now there are seven Companies in Cape Coast. Company feeling runs very high, and a strong esprit de corps exists regarding their customs and emblems.

Cape Coast Castle is what might be called a centralised Oman, as distinguished from the ordinary decentralised bush villages on the Coast, and although the inhabitants have, from time to time, made villages for farming and other purposes outside the town, each of these villages belongs to one of the town Companies, and does not form a new Company of its own.

At Cape Coast riots have been fairly frequent, and are invariably the outcome of an infringement of some custom; in the "bush," riots are much rarer, and chiefly owe their origin to jealousy, or a boundary dispute. In Cape Coast a chief is primarily the Omanhin's councillor rather than a fighting leader, and becomes entirely independent of his Company, as soon as he is enstooled, and becomes, like the Tufuhin, persona grata with all the Companies; in the "bush" a chief is essentially a fighting leader, as well as the political head of several villages.

Having so far dwelt at some length on the officers of each Company, it might be interesting to complete the system by describing some of their properties and customs.

For instance, the Company Post or Essuro is the rallying point of the Company, and each Company has its own post. These are found on that part of the land or town on which the Company has settled, and which it looks upon as peculiarly its own. 
on 14 August 201 


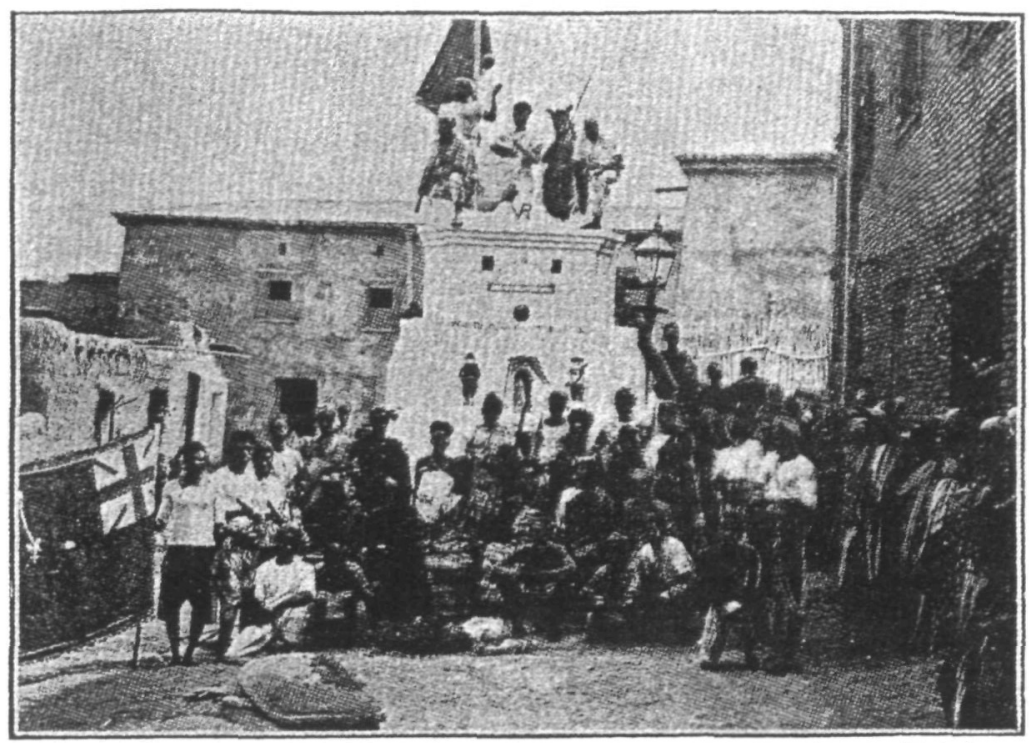

The Company post (Esstero) of No. 5 Co., Cape Coast, showing all the Captains assembled after
the annual custom, and the swish mound, "Essu," in the foreground, protec:ed by a turtle shell.

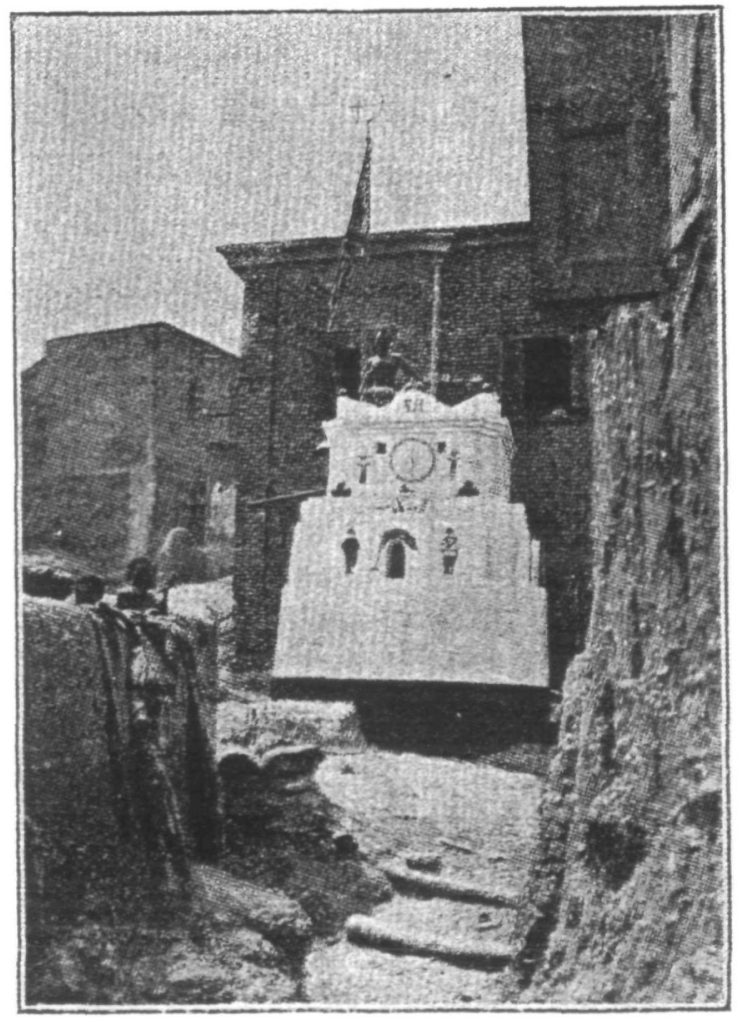

East View of the Company post of No. 5 Co., showing the ornamentations. 
The Company Post consists generally of a circular brick or swish (earth) tower, with one entrance. In this are kept all the paraphernalia of the Company, viz., the drums, flags, horns, caps, emblems, fetiches, and trophies, and the Supi keeps the key. An essential part of this tower is a flag-pole. On ceremonial and other occasions the Company flag is exhibited from this post, and it is the Company's first care to guard its flag from capture or insult.

Under this tower is very often a vault, in which the principal men of the Company have been interred since the origin of the "post"; sometimes it is a spot where some former hero of the Company has died and been buried; or, again, it may have been the ancestral tomb of the Company's principal men before the "post" was erected to mark the spot. In some instances a Company post is merely a small mound marking the spot where the Company has buried a notable enemy slain in battle. In all cases the site of the post, and the post itself, are sacred.

Connected with the post is the Dadikol, which is a piece of iron wrapped round with a bunch of pine-apple fibre. This is stuck into a small mound of earth or Essu, forming the coronation stool, so to speak, of the captains of the Company, as it is at this mound that the captains of the Company are installed at the annual custom, which each Company holds, or should hold, at its own special time. These mounds generally are, but need not be, near the main post, and are usually protected from rain by turtle-shells. For the member of any Company to desecrate this spot, or any other special property of a Company, used to mean a bloody fight between the two Companies, and still means a riot.

Then, again, each Company has, in its quarters, a fetich, or palaver, tree, Induase, considered as one of its sacred possessions, under which the Company's councils, or palavers, are held. The tree is often hedged round with the Ntombe (or fetich boundary) shrub, and inside this enclosure are placed sacrifices, in the form of rotten eggs, sour palmwine, and sometimes $g$ in in flasks. A member of another Company dare not pluck a leaf from this tree.

Each Company also has its drum, Asafochini (Achini means a drum). By its means the drummer (Kyercma) 
assembles the Company, challenges another to fight, and so forth; each Company has its own signal, but the drummers have, otherwise, a common code.

Each Company has its own horns, but for these there is no name in common to all the Companies, as the horn of each represents the cry of some living creature, and each Company names its horn from that animal, or bird. Thus at Cape Coast Castle, where there are seven Companies, the Bentil, or No. I Company, formerly had an ivory horn, made from a small elephant's tusk, which was called Osuro Koko; this has now been superseded by a brass trumpet ( $A$ kessem), and the blower is called Driohem Akessem (the one who blows the trumpet).

The Anafo, or No. 2 Company, claims a wooden horn imitating the call of the African black horn-bill (Sphaglobus atratus, in Fanti, Orwam).

The Intsin, or No. 3 Company, formerly had a wooden whistle, which it has now exchanged for one of metal, and also a bell.

The Inkum, or No. 4 Company, once had a wooden horn, which sounded like the cry of a female "wolf," 1 but it has now substituted a brass bugle (Begu), which was presented to the Company by the original Swanzy, of the firm of that name.

The Brofu-Mba, or No. 5 Company, has appropriated a wooden rattle, or Kakrade.

The Akrampa, or No. 6 Company, has a regular drum and fife band, to show their European origin, and the mulattoes were at one time the only persons in Cape Coast who were entitled to play these drums and fifes.

The Amanfur, or No. 7 Company, uses a horn which sounds like the cry of the male "wolf," or Patieka.

Asafo Franki, or Company flags, are amongst the most important of Company emblems, and each Company depicts something on its flags, to copy which is the most deliberate form of challenge to that Company, as one Company can only use the symbols of another by right of conquest.

$$
\text { ' [Wild dog-Lycaon pictus ?-ED.] }
$$


It is customary, all over the Coast, for a chief, when passing in state through the village of another to pay his respects to the latter, and this is usually accompanied by an exchange of gifts. This custom is also observed between Companies, and the tribute now exacted by a Company for allowing another to pass peacefully through its quarters is a double flask of gin, sent beforehand to the Supi, who shares it with the other captains. When this gin is not sent, or is not accepted, a mob at once collects to prevent the trespassers from passing, and this is the most frequent cause of riots at Cape Coast.

Each Company finally holds its annual custom, when its fetich customs are observed, the pine-apple fibre round the Dadikol is renewed, captains are installed, and marriages celebrated during the past year are announced.

A man notifies his marriage to his Company by presenting his wife or wives to the assembled Company, and a double flask of gin to the captains. When this is done, the Company guarantees the protection of his conjugal rights, and if a member of his Company seduces any of these wives, he becomes liable to double the usual satisfaction or Mpata, as he has been specially notified; if the member of any other Company does so and makes any difficulty about paying damages, the Company, by accepting the gin, binds itself to enforce payment in a body.

Captaincies descend from father to eldest son, as valour descends by strength; but if a son is undutiful, or in any other way unfit, the father may in his lifetime notify the fact to his Company, disown his eldest, and name any of his other sons. On his death, and as soon as ever the deceased captain is buried, the Company "seizes" the successor, and carries him home from the cemetery; hence he is said to be "elected." The successor in many cases tries to escape, because of the expense and responsibility, and if he succeeds at the funeral, the Company must wait until the annual custom before it may again properly seize him; if it fails then, it tries at each successive custom until it gets him; he is then given his father's whip, as his emblem of captaincy. This rule of seizing only at the annual custom is being re- 
laxed, and successors are now seized whenever they can be found.

Each Company has its own season of the year, and its own peculiar features in the custom, but the main principle is the same for all :-

When there are any captains to be installed, the whole Company turns out of the town, the night before the custom, into the " bush," where they have to sleep in the dew. Early next morning the wives of the new Asafohin bring them water to wash, they then proceed to the beach to have a good bath, and the new Asafohin have their heads shorn, ornament themselves with gold trinkets, chains, "Aggrey," and other valuable beads, and parade the town in bright-coloured plush or velvet costumes. Each new Osafohin is surrounded by his own little knot of followers, and the Company, generally, make all the noise they can, firing off as many rounds in their Dane-guns as they can get powder for from the new captains, who have to defray all expenses during the custom. The Company flags are exposed, and carried through the town, by the proper officers, and then the Company retires to the Company post, where the Supi, or next senior captain, cuts off the top of the swish mound or essu, renews the fibre on the dadikol, mixes rum with the swish that is cut off, and anoints the forehead and shoulders of each of the new captains with this mixture of rum and earth, after enumerating the history of the Company and the valorous deeds done by the ancestors of the newly-elected captains. Each new captain has then to swear an oath :- "That whenever called upon, either by day or by night, he must be prepared to answer and defend the cause of the Company with lead and powder." After this marriages are proclaimed, and there is a general drinking at the expense of the new captains before the Company disperses. Finally, after eight days, the Company again parades the town, fires more volleys, and after a good deal more drinking, looks forward to its next custom.

When there are no new captains, the Company merely assembles at its post, renews the fibre round the dadikol, receives newly married members, and sacrifices to its fetich. 
I had the opportunity, recently, to allow an installation of some captains of No. 5 Company in Cape Coast. These installation ceremonies are now becoming rare, as it affords an excellent opportunity for the parading Company to expose the emblem of another Company, to which they are not entitled, and this has invariably led to a riot, so that Commissioners are rather chary of giving the necessary permits.

No. 5 is, as I have stated, the Brofu-Mba (white men's children), or Brofu-Nkua (white men's slaves: Akwa, pl. Nkua, a slave). They were given quarters near the castle, with just a little "bush" in between, and when the castle was completed, these artisans formed a Company, and made a fetich which they called Gyapi (from Egya, father, and $P i$, of many); this they placed under the site of their Company post, in quarters which they named Gyapi-Enim (meaning "in the face of Gyapi").

They also assimilated the fetich, Nanatabir, which was the fetich of the town; this was a big hole, full of snakes and sea-weed, in the rock on which the castle is built. This hole was only filled in about 1874 .

No persons except members of this Company were allowed to work in the castle, and when any woman of No. 5 was pregnant, she was always allowed double pay for any work she did.

When the castle was finished, this Company was allowed the privilege of firing guns, in the castle, at their annual custom, which was made to coincide with our Christmas, -a privilege which they still claim.

On the eve of the custom, viz., December 24th, No. 5 observes a preliminary custom, called Amitsi-Amitsi, when a kind of fufu (porridge) is made with parched corn and dried plantains, over this palm-oil-soup is poured, and a large calabash full is brought to the Company's post, where all the children in No. 5 assemble and eat together, whilst the grown-ups in the Company pass food from house to house.

That night, if there are any new captains, the Company turns out, and after parading the town next morning for the custom proper (Etyeran), the whole procession stops in front of the castle gate, and fires guns, during which time the flag- 
bearer and the Asikanmba take the Company flag into the castle inner yard three times, where a crescent is formed each time and a volley is fired; these three entrances are made in rushes, and accompanied by yells.

This act is peculiar to the custom of No. 5 , and preserves the privilege of their origin; and on the eighth day parade, the whole Company come into the castle, swarm all over the battlements, and fire volleys at will in every part for about an hour; they then retire and go on in a body to their Company post, to finish the custom.

Before allowing this performance, all the principal members of the Company were made to sign a bond in $£ 500$ that no disturbance would take place, by the exposure of another Company's flags, or by passing through another Company's land without paying the customary flask of gin. In addition to this, I reserved the right to be personally present during any part of the proceedings, in case any attempt were made at human sacrifices, as this was one of the occasions, before rum was substituted, of spilling blood on the mound (essu) near the Company post.

The Companies are not now very particular about the exact day of the custom; on this occasion, for instance, the custom was postponed from Christmas Day to a fortnight later, as I had taken my cook with me into the bush, and he was one of the five captains who were to be installed. Also, owing to the expense of the gunpowder, rum, clothes, and money that each captain has to provide, to satisfy the whole Company, the installation ceremony is only performed at every fifth or sixth custom, so as to allow the number of vacancies to accumulate, and the expenses to decrease in proportion.

I was shown the different emblems of No. 5 Company, and found two which proved of some interest.

The West African oil-palm produces bunches of nuts, from which the oil is made, and which are considered an emblem of hardness. Each captain at his installation has to add a bunch of these palm-nuts to the Company emblems, together with a hard stone, as a symbol of his staunchness, for "however hard a palm-nut may be, a stone will crack it !"

The second emblem peculiar to No. 5 is a pair of old 


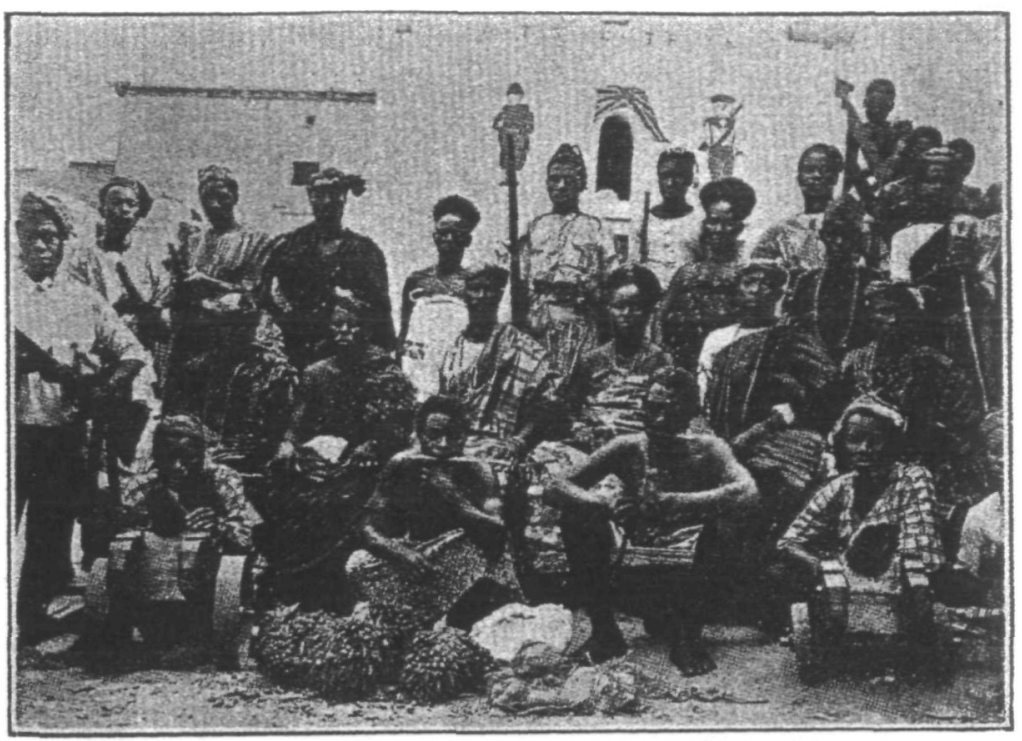

All the Camtains of No. s, ipcloding a woman, who captains the cooking and domeatic amangements. The two "Brafo" are trying to show how they execte their victions The two canpon as their symbol of overcoming overything, we shown in the foreground.

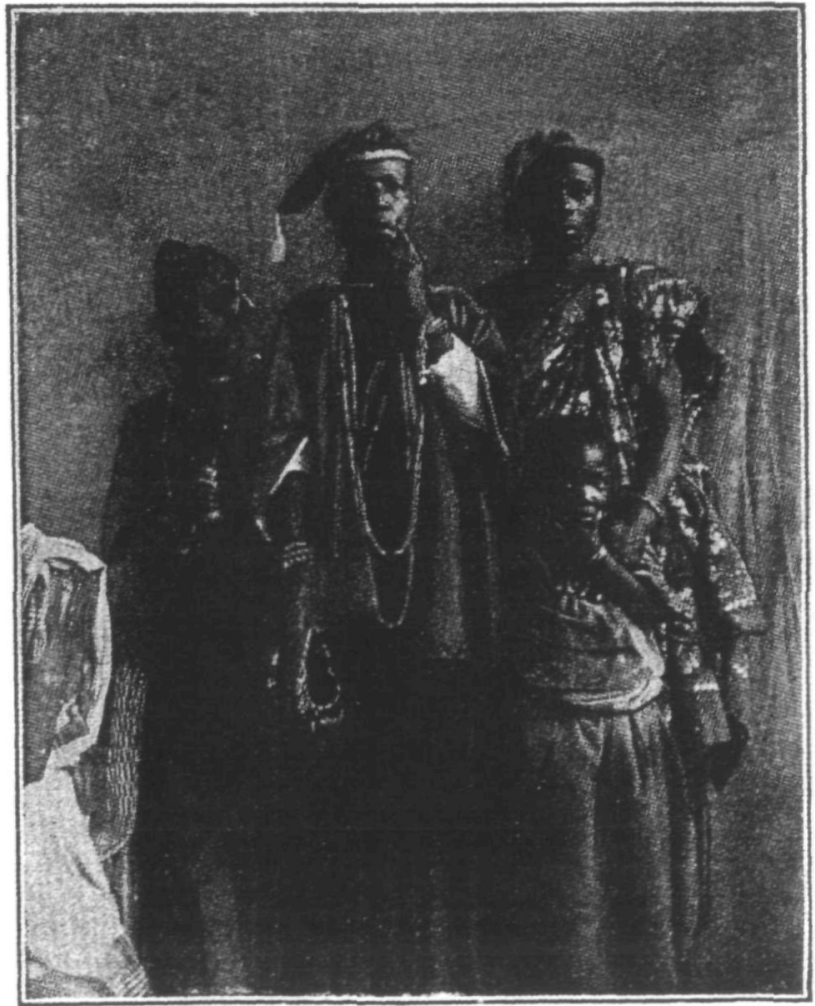

Albert Mbra my cook, one of the newly-elected Captans, holding bis wip in his band

[T. feco mare ate. 
Downloaded from https://academic.oup.com/afraf/article-abstract/VII/XXVII/261/116490

by INSEAD user
on 14 August 2018 
cannon, rather smaller than four-pounders, given to the Company by Captain Maclean, who was Governor under the Committee of Merchants from 1830 to 1836 , and again from 1838 to 1843 , when the Crown resumed these Settlements, and he was made Judicial Assessor. These guns contribute largely to the noise made when the Company parades the town, but their condition makes them rather dangerous toys.

The Company post has depicted on it a soldier and a sailor, on either side of a door, draped with a roughly drawn Union Jack, above which is the motto:-

"When The Signal Calls To Battle."

Above this again is a semi-circle with "Brofoo Mba No. 5 Company" over the words "Cape Caast," the whole being surmounted by the monogram V.R. The eastern side of the post has been brought up to date with the monogram E.R., and instead of the semi-circle and motto, has other symbols, the dial of a clock being the most prominent. The flag-pole is surmounted by a symbolic bow and arrow.

I photographed a group of all the captains installed in 1907, with the bunches of palm-nuts and stones, together with the two cannons, and the Company Abrafo holding their knives in their mouths to impersonate their victims. A more distant view further shows the swish mound covered with the turtle shells, and two of the Company flags.

ARTHUR FFOULKES,

District Commissioner, Gold Coast Colony, W. Africa. 